\title{
Peranan Keputusan Hedging dalam Hubungan Risiko Nilai Tukar Rupiah dan Growth Opportunity terhadap Profitabilitas
}

\author{
Gabriela Santoso ${ }^{1}$ \\ Sekolah Pascasarjana \\ Universitas Katolik Widya Mandala \\ Surabaya, Indonesia
}

\author{
Dyna Rachmawati ${ }^{2}$ \\ Sekolah Pascasarjana \\ Universitas Katolik Widya Mandala \\ Surabaya, Indonesia
}

\begin{abstract}
Surel : dyna@ukwms.ac.id
ABSTRAK

Penelitian ini bertujuan untuk menguji dan menganalisis pengaruh risiko nilai tukar rupiah dan growth opportunity terhadap profitabilitas dengan keputusan hedging sebagai variabel moderasi. Risiko nilai tukar rupiah diukur dengan eksposur nilai tukar, growth opportunity dengan membandingkan MVE dan BVE, keputusan hedging dengan metode dummy, dan profitabilitas dengan net profit margin. Objek penelitian menggunakan perusahaan manufaktur yang terdaftar di BEI periode 2017-2019. Pemilihan sampel menggunakan teknik purposive sampling. Analisis data menggunakan teknik analisis regresi linear dan MRA. Hasil penelitian menunjukkan risiko nilai tukar rupiah bukan merupakan faktor yang mempengaruhi profitabilitas, keputusan hedging dapat mengurangi dampak negatif risiko nilai tukar rupiah terhadap profitabilitas, dan growth opportunity mampu meningkatkan profitabilitas.
\end{abstract}

Kata Kunci: Risiko Nilai Tukar Rupiah; Growth Opportunity; Profitabilitas; Keputusan Hedging.

The Role of Hedging Decisions in the Relationship between The Risk of Rupiah Exchange Rate and Growth Opportunity to Profitability

\section{ABSTRACT}

This study aims to examine and analyze the effect of the risk of rupiah exchange rate and growth opportunity on profitability with hedging decisions as moderating variables. The risk of rupiah exchange rate is measured by exchange rate exposure, growth opportunity is measured by comparing $M V E$ and $B V E$, and hedging decisions are measured by the dummy method, and profitability by net profti margin. The object of research used is manufacturing companies listed on the IDX during 2017-2019 periods. The sample selection used purposive sampling. Data analysis used linear regression analysis technique and MRA. The results showed that the risk of rupiah exchange rate had no effect on profitability, hedging decisions reduced the negative effect of the risk of rupiah exchange rate on profitability, and growth opportunity had a positive effect on profitability.

Keywords: $\quad$ Risk of Rupiah Exhange Rate; Growth Opportunity; Profitability; Hedging Decisions.

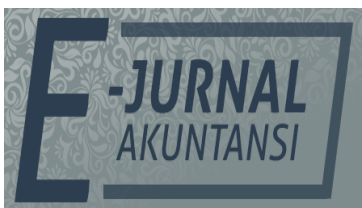

e-ISSN 2302-8556

Vol. 31 No. 10

Denpasar, Oktober 2021

Hal. 2649-2662

DOI:

10.24843/EJA.2021.v31.i10.p19

PENGUTIPAN:

Santoso, G., \& Rachmawati,

D. (2021). Peranan Keputusan

Hedging dalam Hubungan

Risiko Nilai Tukar Rupiah dan Growth Opportunity terhadap Profitabilitas. EJurnal Akuntansi, 31(10),

2649-2662

RIWAYAT ARTIKEL:

Artikel Masuk:

2 Juli 2021

Artikel Diterima: 22 Oktober 2021

Artikel dapat diakses : https://ojs.unud.ac.id/index.php/Akuntansi/index 


\section{PENDAHULUAN}

Perdagangan internasional menjadi lebih mudah pada era globalisasi ini. Perdagangan internasional merupakan sebuah kesepakatan yang dibentuk oleh dua negara yang memiliki tujuan untuk memenuhi kegiatan ekonomi dan perdagangan di setiap negara yang berwujud dagang atau jasa yang sifatnya saling menguntungkan (Feriyanto, 2015), dan (Griffin \& Pustay, 2015). Namun perdagangan internasional mempunyai risiko lebih tinggi apabila dibandingan dengan perdagangan lokal atau dalam negeri karena berkaitan dengan 2 negara yang memiliki mata uang yang berbeda risiko tersebut berkaitan dengan perbedaan nilai tukar mata uang yang berubah secara dinamis (Ayuningtyas, et al., 2019). Faktor lain yang membuat perdagangan internasional berisiko adalah kondisi eksternal yang sedang terjadi, yaitu pandemi virus corona yang disebut dengan covid-19 memberikan dampak terhadap perekonomian semua negara. Nilai tukar rupiah terhadap dolar pada masa pandemi ini sebesar Rp 16.300 kuartal ke-1 tahun 2020, dan Rp 14.600 kuartal ke-2 tahun 2020. Ini mengindikasikan bahwa pandemi Covid-19 memberikan dampak pada lemahnya daya beli masyarakat internasional, sehingga permintaan impor dan ekspor menurun

Di Indonesia, menurut Bank Indonesia (BI) fluktuasi nilai tukar rupiah terhadap dolar mengalami banyak perubahan, namun nilai tukar rupiah semakin lemah terhadap dolar selama tahun 2012-2015. Hal ini memberikan risiko pada perusahaan yang mempunyai hutang dalam mata uang dolar. Risiko nilai tukar yang fluktuatif dapat mempengaruhi profitabilitas perusahaan, nilai tukar atau kurs merupakan nilai mata uang yang dapat diubah kedalam mata uang lainnya dimana perbandingan nilai tersebut dikendalikan oleh kondisi pasar yang terdapat penawaran dan permintaan mata uang tersebut yang tidak dapat diprediksi secara pasti sehingga apabila fluktuasi nilai tukar rupiah yang semakin menurun terhadap mata uang asing termasuk mata uang yang sering dipergunakan di seluruh dunia yaitu Dolar membuat perusahaan lokal rentan mengalami kerugian selisih nilai kurs apabila memiliki transaksi kepada perusahaan atau pihak asing yang nantinya akan berdampak kepada laba perusahaan (Kinasih \& Mahardhika, 2019). Penelitian terdahulu yang menguji pengaruh risiko nilai tukar rupiah terhadap profitabilitas masih belum konklusif. Lailiyah (2017) dan Setyaningsih, et al., (2018) membuktikan bahwa risiko nilai tukar rupiah berpengaruh negatif terhadap profitabilitas. Sedangkan Hidayati (2014) dan Sari \& Baskara (2018) menunjukkan bahwa nilai tukar rupiah berpengaruh positif terhadap profitabilitas. Ulfa, et al., (2016), Prasetyo \& Darmawan (2017), dan Yeboah \& Takacs (2019) membuktikan bahwa nilai tukar rupiah tidak berpengaruh terhadap profitabilitas.

Penelitian terdahulu masih belum memasukkan aspek manajemen risiko dalam menguji pengaruh risiko nilai tukar rupiah terhadap profitabilitas. Manajemen risiko pada penelitian ini menggunakan keputusan hedging. Hedging merupakan salah satu cara manajemen risiko menggunakan instrumen derivatif keuangan berupa kontrak dengan tujuan melindungi perusahaan terhadap risiko spesifik seperti fluktuasi nilai tukar valuta asing (Aritonang, et al., 2018) dan (Higgins, 2016). Perusahaan yang menggunakan keputusan hedging akan mampu mengurangi dampak negatif risiko nilai tukar rupiah terhadap profitabilitas. 
Sedangkan perusahaan yang tidak mengambil keputusan hedging akan mengalami penurunan profitabilitas yang disebabkan oleh risiko nilai tukar rupiah. Belum banyak penelitian yang menguji keputusan hedging sebagai moderasi. Oleh karena itu, penelitian ini menguji peranan keputusan hedging sebagai moderasi dalam hubungan antara risiko nilai tukar rupiah terhadap profitabilitas.

Growth opportunity merupakan kondisi yang memberikan peluang bagi perusahaan untuk meningkatkan profitabilitasnya. Peluang tumbuh ini dapat dilihat dari berbagai proyek yang dibuat oleh perusahaan untuk meningkatkan kegiatan operasionalnya. Perusahaan akan memilih proyek-proyek yang memberikan net present value (NPV) positif. Proyek-proyek ini didanai dari laba ditahan yang mempunyai risiko rendah. Penelitian-penelitian terdahulu telah menguji pengaruh growth opportunity terhadap profitabilitas. Hasil penelitian terdahulu membuktikan bahwa growth opportunity berpengaruh positif terhadap profitabilitas (Ariska \& Wiyanto, 2019), (Cooper \& Maio, 2018), dan (Setiyowati, et al., 2020). Hutchinson \& Gul (2004) menyatakan bahwa growth opportunity berpengaruh negatif terhadap profitabilitas. Sari \& Sidiq (2013) dan Isik (2017) menunjukkan bahwa growth opportunity tidak berpengaruh terhadap profitabilitas. Perbedaan hasil penelitian terdahulu disebabkan oleh perbedaan pengukuran growth opportunity. Penelitian ini mengukur growth opportunity berdasarkan perbandingan nilai buku ekuitas terhadap nilai pasar ekuitas (Sianturi \& Pangestuti, 2015).

Penelitian ini mempunyai tujuan untuk menguji pengaruh peluang risiko eksternal dan peluang manfaat internal terhadap profitabilitas. Risiko nilai tukar rupiah merupakan faktor yang tidak dapat dikendalikan secara langsung oleh manajemen. Oleh karena itu, manajemen risiko dibutuhkan untuk memitigasi dampak negatif risiko nilai tukar rupiah terhadap profitabilitas. Manajemen risiko yang dilakukan oleh perusahaan adalah keputusan hedging. Keputusan hedging bertujuan untuk mengurangi dampak negatif risiko nilai tukar terhadap profitabilitas. Growth opportunity merupakan peluang manfaat yang dapat dikendalikan oleh manajemen. Growth opportunity merupakan keputusan internal manajemen dalam mengembangkan operasionalnya untuk mengoptimalkan profitabilitas. Perusahaan dalam kondisi growth opportunity dilihat dari proyekproyek yang dikerjakannya untuk meningkatkan kegiatan operasional. Perusahaan memilih proyek-proyek yang memberikan net present value (NPV) positif bagi perusahaan. Proyek-proyek tersebut didanai dari modal sendiri yang berasal dari laba ditahan. Pendanaan internal mempunyai peluang risiko rendah, sehingga keputusan hedging pada model penelitian ini tidak digunakan sebagai pemoderasi dalam hubungan antara growth opportunity terhadap profitabilitas.

Hasil penelitian ini menunjukkan bahwa pertama, risiko nilai tukar rupiah negatif dan tidak signifikan terhadap profitabilitas. Ini berarti bahwa risiko nilai tukar rupiah mengurangi profitabilitas sangat lemah sehingga secara statistik tidak signifikan. Kedua, keputusan hedging mempunyai peranan sebagai pemoderasi dalam hubungan antara risiko nilai tukar rupiah terhadap profitabilitas. Keputusan hedging mampu mengurangi dampak negatif risiko nilai tukar rupiah terhadap profitabilitas. Ketiga, growth opportunity berpengaruh positif terhadap profitabilitas. 
Penelitian ini menggunakan dua variabel kontrol yaitu kebijakan deviden dan ukuran perusahaan. Kebijakan dividen merupakan keputusan perusahaan untuk memberikan sebagian laba untuk dibayarkan kepada pemegang saham dalam bentuk dividen tunai dan sebagian laba digunakan untuk mengembangkan usaha namun keputusan ini membutuhkan banyak pertimbangan karena tujuan perusahaan tidak semerta-merta memperluas jangkauan perusahaan namun juga kepuasan pemegang saham (Annisa \& Puryandani, 2019), (Harmono, 2014), dan (Haryanti, 2012). Penggunaan kebijakan dividen yang signifikan dapat dikatakan bahwa perusahaan memiliki kinerja operasional baik yaitu dengan menghasilkan laba setiap tahunnya. Hasil penelitian terdahulu telah menunjukkan konsistensi bahwa kebijakan deviden berpengaruh positif terhadap profitabilitas (Farrukh, et al., 2017), (Khan, et al., 2019), (Khan, et al., 2016) dan (Purnama, 2018). Perusahaan yang membagikan deviden adalah perusahaan dengan tingkat profitabilitas tinggi pula. Hasil penelitian ini mengkonfirmasikan hasil penelitian terdahulu bahwa kebijakan deviden berpengaruh positif terhadap profitabilitas. Kebijakan deviden mengindikasikan adanya sisa laba yang akan dibagikan kepada investor.

Variabel kontrol yang kedua yaitu ukuran perusahaan. Ukuran perusahaan digunakan sebagai gambaran besar kecilnya perusahaan, semakin besar perusahaan maka dianggap bahwa memiliki reputasi yang baik sehingga dapat lebih mudah mendapatkan pinjaman dari pihak eksternal baik dalam bentuk hutang atau modal saham (Puspitasari \& Suryono, 2020). Semakin besar suatu perusahaan maka akan semakin mendapat perhatian masyarakat sehingga manajemen akan berusaha untuk memiliki kinerja yang baik agar dapat menghasilkan laba yang tinggi untuk menjaga reputasi terhadap pandangan publik (Aprinaningsih \& Yushita, 2016). Penelitian terdahulu juga telah membuktikan secara konsisten bahwa ukuran perusahaan berpengaruh positif terhadap profitabilitas (Dogan, 2013), (Melia \& Yulius, 2015), (Omenyo \& Muturi, 2019), dan (Wardani \& Rudolfus, 2016). Hasil penelitian ini membuktikan bahwa ukuran perusahaan tidak berpengaruh terhadap profitabilitas. Ini berarti tidak ada perbedaan kemampulabaan antara perusahaan besar dengan perusahaan kecil.

Risiko nilai tukar adalah fluktuasi nilai tukar rupiah terhadap mata uang asing. Fluktuasi ini disebabkan oleh ketidakpastian faktor makro seperti perekonomian, persaingan perdagangan internasional, intervensi otoritas bank sentral, politik, dan masih banyak lagi. Fluktuasi nilai tukar rupiah yang tidak pasti ini memberikan risiko bagi perusahaan dengan hutang dalam valuta asing. Hasil penelitian terdahulu telah membuktikan bahwa risiko nilai tukar rupiah berpengaruh negatif terhadap profitabilitas (Lailiyah, 2017), (Mansyur, 2018), (Parlak \& Ilhan, 2016), dan (Setyaningsih et al., 2018). Risiko nilai tukar rupiah mengancam perolehan profitabilitas perusahaan.

$\mathrm{H}_{1 \mathrm{a}}$ : Risiko nilai tukar rupiah berpengaruh negatif terhadap profitabilitas.

Risiko nilai tukar rupiah ini harus dikelola dengan baik oleh perusahaan sehingga dapat mengurangi penurunan profitabilitas. Pengelolaan risiko nilai tukar rupiah ini dapat dilakukan dengan mengambil keputusan hedging. Hedging merupakan keputusan yang dilakukan oleh perusahaan dengan menukarkan valuta asing dimasa yang akan datang dengan mata uang lokal untuk melindungi aktiva perusahaan atau menghindari kerugian atas valuta asing dari nilai tukar yang berfluktuasi dalam transaksi bisnis (Guniarti, 2014). Keputusan hedging 
dapat meminimalisir dampak negatif terhadap profitabilitas yang disebabkan oleh risiko nilai tukar rupiah.

$\mathrm{H}_{1 \mathrm{~b}}$ : Keputusan hedging memperlemah pengaruh negatif nilai tukar Rupiah terhadap profitabilitas.

Growth opportunity merupakan peluang bagi perusahaan untuk meningkatkan kegiatan operasional melalui proyek-proyek yang mendapatkan net present value (NPV) positif. Perusahaan dengan peluang tumbuh memiliki nilai investasi tinggi dalam mengembangkan aset tetap perusahaan. Investasi tersebut dapat berupa pembelian pabrik maupun mesin baru, program research and development, memperluas pasar, dan lainnya. Manajemen berusaha untuk meningkatkan pangsa pasar dan mempertahankan kualitas produk agar dapat memiliki laba yang tinggi untuk melakukan investasi tersebut. Sehingga semakin tinggi peluang tumbuh perusahaan maka profitabilitas perusahaan akan semakin tinggi juga. Perusahaan yang memiliki pertumbuhan yang baik juga dianggap memiliki profitabilitas yang baik karena mampu memperluas bidang usahanya. Penelitian yang telah dilakukan oleh Cooper \& Maio (2018), Ariska \& Wiyanto (2019), dan Setyowati, Nasser, \& Astuti (2020) membuktikan bahwa growth opportunity berpengaruh positif terhadap profitabilitas.

$\mathrm{H}_{2}$ : Growth opportunity berpengaruh positif terhadap profitabilitas.

\section{METODE PENELITIAN}

Populasi penelitian adalah perusahaan manufaktur yang terdaftar di Bursa Efek Indonesia (BEI), karena perusahaan manufaktur memiliki proses bisnis yang cukup kompleks. Teknik penyampelan yang digunakan adalah purposive sampling. Tabel 1, menunjukkan kriteria penyampelan dan jumlah data tahun perusahaan.

Tabel 1. Jumlah Sampel

\begin{tabular}{lc}
\hline Keterangan & Jumlah \\
\hline Populasi & 155 \\
Perusahaan manufaktur yang terdaftar di BEI selama periode & \\
2017-2019 & \\
Tidak Memenuhi Kriteria & 39 \\
a. Perusahaan yang menyediakan laporan tahunan dan & \\
$\quad$ sudah diaudit oleh Kantor Akuntan Publik (KAP) & 17 \\
b. Perusahaan yang menyajikan laporan keuangan dalam & 4 \\
$\quad$ mata uang Rupiah & 95 \\
c. Perusahaan yang tidak delisting selama tahun penelitian & 3 \\
Jumlah Perusahaan yang Digunakan & 285 \\
Jumlah Tahun Pengamatan & 139 \\
Jumlah Sampel Digunakan & 146 \\
Data Outlier & \\
Jumlah Data Observasi (n) &
\end{tabular}

\section{Sumber: Data Penelitian, 2021}

Berdasarkan Tabel 1, jumlah populasi yang dimiliki yaitu 155 perusahaan, namun adanya perusahaan yang tidak memeluhi kriteria sampel maka didapatkan 95 perusahaan dengan jumlah pengamatan 3 tahun sehingga didapatkan 285 data sampel. Terdapat beberapa data sampel yang dikeluarkan dari penelitian atau data outlier karena memiliki nilai ekstrim yang dapat menyebabkan data tidak normal sehingga hasil akhir jumlah sampel yang 
digunakan yaitu 146 data. Definisi dan operasionalisasi variabel disajikan pada Tabel 2, sebagai berikut.

\section{Tabel 2. Definisi dan Operasionalisasi Variabel}

\begin{tabular}{|c|c|c|c|}
\hline Variabel & Definisi & Operasionalisasi & Referensi \\
\hline $\begin{array}{l}\text { Profitabilita } \\
\mathrm{s}\end{array}$ & $\begin{array}{l}\text { Capaian kinerja } \\
\text { marjin laba } \\
\text { yang dihasilkan } \\
\text { dari penjualan }\end{array}$ & $\begin{array}{l}\text { Net profit margin: } \\
\qquad P R O=\frac{\text { Net Profit }}{\text { Sales }}\end{array}$ & $\begin{array}{l}\text { Ahmad et } \\
\text { al. (2015) }\end{array}$ \\
\hline $\begin{array}{l}\text { Risiko nilai } \\
\text { tukar } \\
\text { rupiah }\end{array}$ & $\begin{array}{l}\text { Fluktuasi nilai } \\
\text { tukar rupiah } \\
\text { terhadap mata } \\
\text { uang asing }\end{array}$ & $\begin{array}{l}\text { Eksposur nilai tukar ditentukan dengan } \\
\text { koefisien regresi } \gamma_{i} \text { dari persamaan } \\
\text { regresi: } \\
R_{i}=\alpha_{i}+\beta_{i} R m-\gamma_{i} X R_{i}+\varepsilon_{i}\end{array}$ & $\begin{array}{l}\text { Sasmitap } \\
\text { ura \& } \\
\text { Djajadike } \\
\text { rta (2021) }\end{array}$ \\
\hline & & $\begin{array}{l}R_{i}=\text { return saham } \mathrm{i} \\
R m=\text { return pasar }(\mathrm{IHSG}) \\
X R_{i}=\text { selisih kurs }\end{array}$ & \\
\hline $\begin{array}{l}\text { Growth } \\
\text { opportunity }\end{array}$ & $\begin{array}{l}\text { Peluang } \\
\text { perusahaan } \\
\text { untuk } \\
\text { bertumbuh } \\
\text { karena } \\
\text { memiliki } \\
\text { proyek-proyek } \\
\text { dengan arus kas } \\
\text { positif }\end{array}$ & $\begin{array}{l}\quad M V E=\frac{E A T}{E P S} \times \text { Closing Price } \\
B V E=\text { Total Aset }- \text { Total Liabilitas } \\
\qquad G O=\frac{M V E}{B V E} \\
\mathrm{MVE}=\text { market value of equity } \\
\mathrm{BVE}=\text { book value of equity } \\
\mathrm{EAT}=\text { earnings after tax } \\
\mathrm{EPS}=\text { earnings per share }\end{array}$ & $\begin{array}{l}\text { Ariska \& } \\
\text { Wiyanto } \\
\text { (2019) }\end{array}$ \\
\hline $\begin{array}{l}\text { Keputusan } \\
\text { hedging }\end{array}$ & $\begin{array}{l}\text { Manajemen } \\
\text { risiko dengan } \\
\text { instrument } \\
\text { derivatif untuk } \\
\text { mengantisipasi } \\
\text { terjadinya } \\
\text { fluktuasi nilai } \\
\text { tukar rupiah }\end{array}$ & $\begin{array}{l}\text { Variabel dummy: skor } 1 \text { untuk perusahaan } \\
\text { yang mengambil keputusan hedging, } \\
\text { sebaliknya skor } 0 \text { untuk perusahaan yang } \\
\text { tidak mengambil keputusan hedging. }\end{array}$ & $\begin{array}{l}\text { Ariton- } \\
\text { ang, Daat, } \\
\& \\
\text { Andriati } \\
(2018)\end{array}$ \\
\hline $\begin{array}{l}\text { Kebijakan } \\
\text { deviden }\end{array}$ & $\begin{array}{l}\text { Kebijakan } \\
\text { perusahaan } \\
\text { untuk } \\
\text { membayar } \\
\text { deviden dari } \\
\text { laba ditahan }\end{array}$ & $\frac{\text { dividen yang dibagi }}{\text { Earning After Tax }}$ & $\begin{array}{l}\text { Lestari et } \\
\text { al. (2016) }\end{array}$ \\
\hline $\begin{array}{l}\text { Ukuran } \\
\text { perusaha- } \\
\text { an }\end{array}$ & $\begin{array}{l}\text { Besar kecilnya } \\
\text { aset yang } \\
\text { dimiliki oleh } \\
\text { perusahaan }\end{array}$ & Ukuran Perusahaan $=$ Ln_TotalAsset & $\begin{array}{l}\text { Dogan } \\
(2013)\end{array}$ \\
\hline
\end{tabular}

Sumber: Data Penelitian, 2021

Penelitian ini menggunakan moderated regression analysis (MRA) untuk menguji hipotesis. Persamaan (1) dalam penelitian ini, yaitu sebagai berikut. $P R O=a_{1}+\beta_{1} N T+\beta_{2} G O+\beta_{3} H E D * N T+\beta_{4} K D+\beta_{5} U K+\epsilon$

Keterangan:

$$
\begin{array}{ll}
\alpha & : \text { Konstanta } \\
\beta & : \text { Koefisien Regresi }
\end{array}
$$




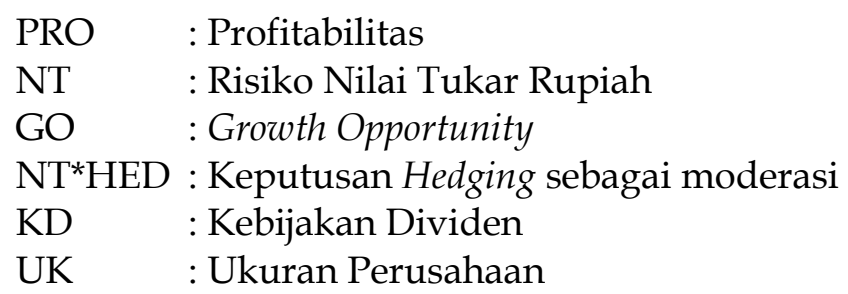

MRA yang berbasiskan ordinary least squares (OLS) harus melalui beberapa tahapan pengujian sebelum pengujian hipotesis, uji normalitas, uji asumsi klasik yang meliputi, uji heteroskedastisitas, autokorelasi, multikolinearitas, dan uji kelayakan model.

\section{HASIL DAN PEMBAHASAN}

Statistik deskriptif digunakan untuk menunjukkan distribusi frekuensi nilai dari masing-masing variabel yaitu: profitabilitas (PRO), risiko nilai tukar rupiah (NT), growth opportunity (GO), keputusan hedging (HED), kebijakan deviden (KD), dan ukuran perusahaan (UK).

Tabel 3. Statistik Deskriptif

\begin{tabular}{llcccc}
\hline & $\mathrm{N}$ & Minimum & Maksimum & Mean & Std. Deviasi \\
\hline PRO & 146 & $-0,11$ & 0,16 & 0,02 & 0,04 \\
NT & 146 & $-0,64$ & 1,02 & 0,24 & 0,34 \\
GO & 146 & $-0,26$ & 2,74 & 0,91 & 0,56 \\
HED & 146 & 0 & 1 & 0,34 & 0,47 \\
KD & 146 & $-3,03$ & 5,81 & 1,25 & 1,64 \\
UK & 146 & 18,4 & 24,17 & 21,23 & 1,19 \\
\hline
\end{tabular}

Sumber: Data Penelitian, 2021

Tabel 3, menunjukkan bahwa nilai minimum profitabilitas (PRO) yang diukur dengan net profit margin (NPM) sebesar -0,11. Ini berarti perusahaan tersebut mengalami kerugian. NPM mempunyai nilai paling tinggi sebesar 0,16. Nilai mean sebesar 0,02 dengan standar deviasi relatif rendah yaitu 0,04. Hal ini mengindikasikan NPM atau profitabilitas perusahaan sampel relatif kecil.

Risiko nilai tukar rupiah (NT) memiliki nilai minimum -0,64. Ini mengindikasikan eksposur risiko nilai tukar rupiah terhadap dolar sangat tinggi. Sedangkan nilai maksimum 1,02 mengindikasikan eksposur risiko nilai tukar rupiah rendah. Variabel ini mempunyai nilai mean sebesar 0,24 dengan standar deviasi 0,34 . Hal ini mengindikasikan eksposur risiko nilai tukar rupiah pada perusahaan sampel cukup rendah.

Growth opportunity (GO) yang diproksikan dengan perbandingan nilai pasar ekuitas terhadap nilai buku ekuitas memiliki nilai minimum -0,26. Nilai minus dapat terjadi apabila perusahaan memiliki laba negatif. Ini mengindikasikan perusahaan tidak mempunyai growth opportunity. Sedangkan nilai maksimum sebesar 2,74 yang berarti growth opportunity sangat tinggi. Variabel ini mempunyai nilai mean sebesar 0,91 dengan standar deviasi 0,56. Hal ini mengindikasikan perusahaan sampel mempunyai peluang tumbuh cukup tinggi.

Keputusan hedging (HED) diukur dengan menggunakan variabel dummy. Nilai mean sebesar 0,34 menunjukkan bahwa perusahaan sampel yang mengambil keputusan hedging sebesar 34 persen, dan sisanya 66 persen tidak mengambil keputusan hedging. 
Kebijakan dividen (KD) diukur dengan deviden yang dibayarkan kepada pemegang saham dibagi dengan laba setelah pajak. Nilai minimum sebesar -3,03 menunjukkan bahwa perusahaan yang membagikan deviden mengalami kerugian pada tahun berjalan. Deviden yang dibagikan pada tahun berjalan merupakan deviden dari laba pada tahun sebelumnya. Nilai maksimum sebesar 5,81 yang berarti deviden yang dibayarkan 5 kali lipat dari laba setelah pajak. Variabel ini mempunyai nilai mean sebesar 1,25 dengan standar deviasi relatif tinggi 1,64. Hal ini mengindikasikan rata-rata perusahaan sampel membagikan dividen 1 kali lipat dibandingkan labanya.

Ukuran perusahaan (UP) yang diproksikan dengan total aset memiliki nilai mean sebesar 21,23 dengan standar deviasi 1,19. Hal ini mengindikasikan perusahaan sampel memiliki ukuran perusahaan yang cukup besar apabila dilihat dari total asetnya. Kemudian langkah selanjutnya sebelum menguji hipotesis yaitu sebagai berikut.

Tabel 4. Hasil Uji Normalitas

\begin{tabular}{lcc}
\hline Keterangan & Unstandardized Residual & Kesimpulan \\
\hline Asymp. Sig. (2-tailed) & 0,347 & Distribusi nilai residu normal \\
\hline Sumber: Data Penelitian, 2021 & &
\end{tabular}

Tabel 4, menunjukkan bahwa nilai signifikansi sebesar 0,347, lebih besar dari p-value 0,05 . Ini berarti distribusi nilai residu pada persamaan (1) normal. Tahap ke-2a adalah uji heteroskedastisitas dengan uji Harvey. Hasil uji Harvey dilakukan dengan meregresikan $\log 10\left(\right.$ resid $\left.^{2}\right)$ sebagai variabel dependen terhadap semua variabel independen pada persamaan (1). Hasil pengujian menunjukkan nilai signifikansi sebesar 0,0986 yang lebih besar dari p-value 0,05. Ini berarti terjadi homoskedastisitas.

Tahap ke-2b adalah uji autokorelasi dengan uji Durbin Watson. Nilai Durbin Watson pada persamaan (1) sebesar 1,938. Pengujian berdasarkan Tabel Durbin Watson dengan $\mathrm{k}=5$ dan $\mathrm{n}=146$, maka $\mathrm{dU}=1,8008$ sehingga dengan mengikuti rumus $\mathrm{du}<\mathrm{dw}<4$-du $(1,8008<1,938<4-1,8008)$ maka dapat dikatakan bahwa tidak terjadi autokolerasi.

Tahap ke-2c adalah uji multikolinearitas untuk memastikan tidak adanya korelasi antar variabel independen. Uji multikolinearitas menggunakan uji TOL dan VIF. Tabel 4, menunjukkan hasil uji multikolinearitas.

Tabel 5. Hasil Uji Multikolinearitas

\begin{tabular}{lccc}
\hline Variabel & Tolerance & VIF & Kesimpulan \\
\hline Independen & $>0,1$ & $<10$ & \\
NT & 0,582 & 1,718 & Tidak Terjadi Multikolinearitas \\
GO & 0,708 & 1,413 & Tidak Terjadi Multikolinearitas \\
HED & 0,221 & 4,533 & Tidak Terjadi Multikolinearitas \\
NT_HED & 0,332 & 3,013 & Tidak Terjadi Multikolinearitas \\
KD & 0,886 & 1,128 & Tidak Terjadi Multikolinearitas \\
UK & 0,796 & 1,256 & Tidak Terjadi Multikolinearitas \\
\hline
\end{tabular}

Sumber: Data Penelitian, 2021

Tabel 4, menunjukkan tidak terjadi multikolinearitas antar variabel independen. Tahap ke-3 adalah uji kelayakan model. Uji kelayakan model menggunakan uji ANOVA dan $\mathrm{R}^{2}$. Hasil uji $\mathrm{F}$ (ANOVA) menunjukkan nilai 
signifikansi 0,000. Nilai ini di atas p-value 0,05. Ini berarti model penelitian pada persamaan (1) adalah layak digunakan untuk menguji hipotesis. Nilai $R^{2}$ sebesar 0 ,28. Ini berarti semua variabel independen mampu menjelaskan variabel dependen sebesar 28 persen. Model penelitian pada persamaan (1) telah lolos uji (1) normalitas, (2) asumsi klasik, dan (3) kelayakan model. Tahapan berikutnya adalah pengujian hipotesis yang dijelaskan pada sub bab Hasil dan Pembahasan.

Tabel 6. Uji Hipotesis

\begin{tabular}{lcccc}
$\begin{array}{l}\text { Variabel } \\
\text { Independen }\end{array}$ & Koefisien & t-statistik & Signifikansi & Kesimpulan \\
\hline NT & $-0,00$ & $-0,52$ & 0,60 & $\mathrm{H}_{1 \mathrm{a}}$ Ditolak \\
NT*HED & 0,04 & 1,97 & $0,05^{* *}$ & $\mathrm{H}_{1 \mathrm{~b}}$ Diterima \\
GO & 0,02 & 3,46 & $0,00^{* * *}$ & $\mathrm{H}_{2}$ Diterima \\
KD & 0,01 & 5,52 & $0,00^{* * *}$ & \\
UK & $-0,00$ & $-1,29$ & 0,19 & \\
\hline
\end{tabular}

Sumber: Data Penelitian, 2021

Tabel 6, menunjukkan bahwa $\mathrm{H}_{1 a}$ ditolak atau tidak didukung secara empiris. Risiko nilai tukar rupiah (NT) mempunyai signifikansi 0,60 di atas p-value 0,05 . Ini berarti risiko nilai tukar tidak memiliki pengaruh terhadap profitabilitas (PRO). Hal ini dikarenakan berdasarkan nilai mean risiko nilai tukar rupiah pada Tabel 5, sebesar 0,24. Ini mengindikasikan bahwa peluang risiko mata tukar uang rupiah terhadap valuta asing rendah, sehingga tidak cukup mempengaruhi profitabilitas. Ini didukung dengan laporan keuangan yang menunjukkan bahwa 96 atau 65 persen data tahun perusahaan pada sampel penelitian ini yang mempunyai transaksi lokal lebih banyak dibandingkan transaksi internasional. Sehingga ketidakpastian nilai tukar atau fluktuasi nilai tukar di Indonesia yang menyebabkan ketidakpastian pembayaran bagi perusahaan (Kinasih \& Mahardhika, 2019) tidak terlalu berdampak bagi perusahaan sampel. Hasil penelitian ini mendukung hasil penelitian Ulfa, et al. (2016), Prasetyo \& Darmawan (2017) dan Yeboah \& Takacs (2019) yang menunjukkan bahwa risiko nilai tukar rupiah tidak berpengaruh terhadap profitabilitas.

Tabel 6, menunjukkan bahwa $\mathrm{H}_{1 \mathrm{~b}}$ diterima atau didukung secara empiris. Interaksi risiko nilai tukar rupiah dengan keputusan hedging (NT*HED) terhadap profitabilitas (PRO) mempunyai nilai signifikansi 0,05 atau sama dengan $p$-value 0,05 dan positif. Ini menunjukkan bahwa keputusan hedging mampu memitigasi pengaruh negatif risiko nilai mata uang rupiah terhadap profitabilitas. Keputusan hedging sebagai bentuk tindakan manajemen risiko (Higgins, 2016) dalam melindungi nilai transaksi pihak luar negeri terbukti dapat menghindari adanya risiko fluktuasi nilai tukar yang tidak menentu. Hasil penelitian ini membuktikan pentingnya manajemen risiko untuk mengurangi dampak negatif risiko nilai tukar mata uang rupiah terhadap kemampuan perusahaan dalam menghasilkan laba. Perusahaan yang mengambil keputusan hedging dapat melindungi asetnya melalui optimalisasi profitabilitas karena dapat terhindar dari kemungkinan kerugian atas valuta asing dari nilai tukar Rupiah (Guniarti, 2014). Hasil penelitian ini memberikan kontribusi akademik terkait peranan keputusan hedging sebagai pemoderasi. 
Tabel 6, menunjukkan bahwa $\mathrm{H}_{2}$ diterima atau didukung secara empiris. Nilai signifikansi sebesar 0,00 di bawah $p$-value 0,01 . Ini berarti growth opportunity (GO) terhadap profitabilias (PRO) adalah signifikan dan positif. Hal ini mengindikasikan bahwa perusahaan menjalankan investasi proyek yang mempunyai arus kas positif dalam mengembangkan kegiatan operasionalnya, sehingga mampu meningkatkan profitabilitasnya. Investasi tersebut dapat berupa berupa pembelian pabrik maupun mesin baru, program research and development, memperluas pasar, dll (Widyagoca \& Lestari, 2016). Tabel 5, menunjukkan nilai mean growth opportunity sebesar 91 persen. Ini berarti rata-rata perusahaan sampel penelitian ini mempunyai potensi untuk bertumbuh. Dengan kata lain, perusahaan sampel penelitian ini mempunyai proyek-proyek pengembangan yang mampu meningkatkan profitabilitasnya. Hasil penelitian ini mendukung hasil penelitian Cooper \& Maio (2018), Ariska \& Wiyanto (2019), dan Setyowati et al. (2020) yang telah membuktikan adanya dampak positif growth opportunity terhadap profitabilitas.

Tabel 6, menunjukkan nilai signifikansi kebijakan deviden (KD) terhadap profitabilitas (PRO) sebesar 0,00 di bawah p-value 0,01. Ini berarti kebijakan deviden terhadap profitabilitas adalah signifikan dan positif. Tabel 5, menunjukkan bahwa nilai mean kebijakan deviden 1,25. Ini berarti bahwa rata-rata perusahaan sampel penelitian ini membayar deviden sebesar 1 kali lipat dibandingkan perolehan laba periode tahun berjalan. Deviden yang dibayarkan berasal dari laba tahun lalu, artinya profitabilitas perusahaan sampel tahun lalu lebih tinggi dibandingkan tahun berjalan. Jadi, perusahaan sampel penelitian ini mempunyai kemampuan laba yang baik, sehingga mampu membagikan deviden. Dimana dividen yang dibagikan dapat berupa tunai atau saham dan sesuai dengan porsi setiap pemegang saham (Diantini \& Badjra, 2016). Kebijakan deviden mampu mendorong manajemen untuk meningkatkan profitabilitasnya. Hasil penelitian ini mengkonfirmasikan hasil penelitian Khan et al. (2016), Farrukh, et al. (2017), Purnama (2018), dan Khan, et al. (2019) telah menunjukkan bahwa kebijakan deviden mampu meningkatkan profitabilitas.

Tabel 6, menunjukkan nilai signifikansi ukuran perusahaan (UK) terhadap profitabilitas (PRO) sebesar 0,19 di atas $p$-value 0,05. Ini berarti ukuran perusahaan tidak berpengaruh terhadap profitabilitas. Tabel 5, menunjukkan bahwa nilai mean ukuran perusahaan sebesar 21,23 dengan standar deviasi 1,19. Ini menunjukkan bahwa ukuran perusahaan sampel penelitian ini tidak jauh berbeda, sehingga kemampuannya untuk menghasilkan profitabilitas juga tidak berbeda. Ukuran perusahaan biasanya digunakan sebagai tolak ukur besar kecilnya suatu perusahaan, terdapat beberapa keuntungan apabila suatu perusahaan dianggap besar oleh masyarakat yaitu memiliki kesempatan yang besar untuk mendapatkan investasi dari investor karena perusahaan dianggap memiliki kinerja dan pengendalian internal yang baik sehingga dari investasi yang diberikan oleh investor, maka perusahaan dapat bertahan (Sugiono \& Christiawan, 2013). Hasil penelitian ini bertentangan dengan hasil penelitian yang dilakukan oleh Melia \& Yulius (2015) yang membuktikan secara konsisten bahwa ukuran perusahaan berpengaruh positif terhadap profitabilitas. Hasil penelitian ini memberikan temuan empiris yaitu perusahaan sampel penelitian dengan ukuran yang sama 
maka akan mempunyai kemampuan sama dalam menghasilkan laba. Sehingga secara statistik tidak mempunyai signifikan.

\section{SIMPULAN}

Hasil penelitian ini menyimpulkan bahwa pertama, risiko nilai tukar mata uang rupiah tidak akan mempengaruhi kemampuan perusahaan dalam menghasilkan laba, apabila risiko tersebut kecil. Kedua, perusahaan yang mempunyai peluang risiko nilai tukar mata uang tinggi, sebaiknya melakukan manajemen risiko dengan menerapkan keputusan hedging. Keputusan hedging terbukti secara empiris untuk mengurangi dampak negatif yang diakibatkan oleh risiko nilai tukar mata uang terhadap profitabilitas. Ketiga, perusahaan yang mempunyai growth opportunity akan mampu mengoptimalkan profitabilitasnya. Keempat, kebijakan deviden mampu mendorong manajemen untuk mengoptimalkan kemampuannya dalam menghasilkan laba. Kelima, ukuran perusahaan bukan merupakan faktor yang dapat mempengaruhi perusahaan dalam menghasilkan laba.

Penelitian ini memberikan kontribusi utama secara akademik yaitu peranan keputusan hedging sebagai pemoderasi. Keputusan hedging mempunyai peran untuk mengurangi risiko nilai tukar mata uang yang akan mengurangi profitabilitas. Penelitian selanjutnya dapat menguji kembali peranan hedging sebagai pemoderasi pada industri yang berbeda dari objek penelitian ini, misalnya industri keuangan. Penelitian ini mempunyai keterbatasan yaitu keputusan hedging tidak dibedakan berdasarkan jenisnya: financial hedging dan operational hedging. Penelitian selanjutnya dapat mempertimbangkan perbedaan jenis hedging dalam berperan sebagai mekanisme manajemen risiko.

\section{REFERENSI}

Ahmad, G. N., Mardiyati, U., \& Nashrin, A. S. (2015). Analysis Of Hedging Determinants With Foreign Currency Derivative Instruments On Companies Listed On BEI Period 2012-2015. 6(2), 540-557. https://doi.org/https:// doi.org/10.21009/JRMSI.006.2.03

Annisa, B. C., \& Puryandani, S. (2019). Pengaruh Kesempatan Tumbuh, Ukuran Perusahaan dan Kebijakan Dividen Terhadap Keputusan Hedging. Prosiding Seminar Nasional and Call for Paper, 9(1), 103-114. https://doi.org/http://jp.feb.unsoed.ac.id/index.php/sca1/article/view/1400

Aprinaningsih, A., \& Yushita, A. N. (2016). Pengaruh Penerapan Good Corporate Governance, Struktur Kepemilikan, dan Ukuran Perusahaan Terhadap Kinerja Keuangan Perbankan. Jurnal Profita, 4(4).

Ariska, C., \& Wiyanto, H. (2019). Managerial Ownership , Leverage , Dan Growth Opportunity Sebagai Prediktor Firm Performance Perusahaan Manufaktur Di. Jurnal Manajerial Dan Kewirausahaan, 1(3), 394-400.

Aritonang, E. W. R. B., Daat, S. C., \& Andriati, H. N. (2018). Faktor-faktor Dalam Pengambilan Keputusan Lindung Nilai (Hedging) Pada Instrumen Derivatif Valuta Asing pada Perusahaan yang Terdaftar di Bursa Efek Indonesia. Jurnal Akuntansi Dan Keuangan Daerah, 13, 96-113.

Ayuningtyas, V., Warsini, S., \& Mirati, R. E. (2019). Analisis faktor yang 
mempengaruhi pengambilan keputusan hedging menggunakan instrumen derivatif valuta asing. Politeknik Negeri Jakarta, 6(1), 980-992. https://doi.org/https://jurnal.pnj.ac.id/index.php/acc/article/view/1381

Cooper, I., \& Maio, P. (2018). Asset Growth, Profitability, and Investment Opportunities. Management Science. Management Science, 65(8). https://doi.org/10.1287/mnsc.2018.3036

Diantini, O., \& Badjra, I. B. (2016). Pengaruh Earning Per Share, Tingkat Pertumbuhan Perusahaan dan Current Ratio Terhadap Kebijakan Dividen. EJurnal Manajemen Unud, 5(11), 6795-6824.

Dogan, M. (2013). Does Firm Size Affect The Firm Profitability? Evidence from Turkey Does Firm Size Affect The Firm Profitability? Evidence from Turkey. Does Firm Size Affect the Firm Profitability? Evidence from Turkey, 4(4), 53-57. https://doi.org/https://www.researchgate.net/publication/305222472_Do es_Firm_Size_Affect_The_Firm_Profitability_Evidence_from_Turkey

Farrukh, K., Irshad, S., Khakwani, M. S., Ishaque, S., \& Ansari, N. Y. (2017). Impact of Dividend Policy on Shareholders Wealth and Firm Performance in Pakistan. Cogent Business $\mathcal{E}$ Management, 4(1). https://doi.org/10.1080/23311975.2017.1408208

Feriyanto, A. (2015). Perdagangan Internasional: Kupas Tuntas Prosedur Ekspor Impor. https://doi.org/10.1287/mnsc.2018.3036

Griffin, R. W., \& Pustay, M. W. (2015). Bisnis Internasional: Sebuah Perspektif Manajerial (Vol. 8). Jakarta: Salemba Empat.

Guniarti, F. (2014). Faktor-faktor yang Mempengaruhi Aktivitas Hedging dengan Instrumen Derivatif Valuta Asing. Jurnal Dinamika Manajemen, 5(1), 64-79.

Harmono. (2014). Manajemen Keuangan (Vol. 3). Jakarta: PT. Bumi Askara.

Haryanti. (2012). Pengaruh Agency Cost Terhadap Nilai Perusahaan Dengan Kebijakan Dividen Dan Struktur Modal Sebagai Variabel Intervening. Probank, 20(41), 151331.

Hidayati, A. N. (2014). Pengaruh Inflasi, BI Rate, dan Kurs Terhadap Profitabilitas Bank Syariah di Indonesia. An-Nisbah, 1(1), 1-26.

Higgins, R. C. (2016). Analysis for Financial Management (Vol. 11). New York: McGraw-Hill Education.

Hutchinson, M. R., \& Gul, F. A. (2004). Investment opportunity set, corporate governance practices and firm performance. Journal of Corporate Finance, 10(4), 595-614. https://doi.org/https://doi.org/10.1016/S0929-1199(03)00022-1

Isik, O. (2017). Determinants of Profitability: Evidence from Real Sector Firms Listed in Borsa Istanbul. Business and Economic Research Journal. https://doi.org/10.20409/berj.2017.76

Khan, K., Lamrani, H. C., \& Khalid, S. (2019). The Impact of Dividend Policy on Firm Performance: A Case Study of the Industrial Sector. Risk Governance $\mathcal{E}$ Control: Financial Market $\mathcal{E}$ Institutions, 9(3). https://doi.org/http://doi.org/10.22495/rgcv9i3p2

Khan, M. N., Nadeem, B., Islam, F., Salman, M., \& Gill, H. M. I. S. (2016). Impact of Dividend Policy on Firm Performance: An Empirical Evidence from Pakistan Stock Exchange. American Journal of Economics, Finance and Management, 4(2), 28-34.

Kinasih, R., \& Mahardhika, D. P. K. (2019). Pengaruh Likuiditas, Leverage, Dan 
Nilai Tukar Rupiah Terhadap Penggunaan Instrumen Derivatif Sebagai Keputusan Hedging. Jurnal Ilmiah Manajemen, Ekonomi, Dan Akuntansi, 3(1), 64-80. https:// doi.org/10.31955/mea.vol3.iss1.pp63 - 80

Lailiyah, N. H. (2017). Analisis Pengaruh Inflasi, Bi Rate, dan Nilai Tukar Mata Uang Asing terhadap Profitabilitas Pada Bank Syariah Periode 2011-2015. Institut Agama Islam Negeri Surakarta.

Lestari, F. K., Tanuatmodjo, H., \& Mayasari. (2016). Pengaruh Likuiditas dan Profitabilitas terhadap Kebijakan Dividen. Journal of Business Management Education, $\quad 1(2)$, 236-242. https://doi.org/https://doi.org/10.17509/jbme.v4i1.2293

Mansyur, N. (2018). Pengaruh Risiko Pasar terhadap Profitabilitas Perusahaan Subsektor Bank pada Bursa Efek Indonesia. Jurnal Maksipreneur, 7(2), 107-116. https:// doi.org/10.30588/jmp.v7i2.360

Melia, A. T., \& Yulius, J. C. (2015). Pengaruh Good Corporate Governance terhadap Kinerja Perusahaan pada Sektor Keuangan. Business Accounting Review, 3(1), 223-232.

Omenyo, D. M., \& Muturi, W. (2019). Effect of Firm Size on Financial Performance of Manufacturing Firms Listed in Nairobi Stock Exchange. The Strategic Journal of Business $\mathcal{E}$ Change Management, 6(4), 1112-1119.

Parlak, D., \& Ilhan, H. (2016). Foreign Exchange Rate and Financial Performance: The Case of Turkey. International Review of Economics and Management, 4(2), 115. https://doi.org/10.18825/irem.37893

Prasetyo, D. A., \& Darmawan, A. (2017). Pengaruh Risiko Inflasi, Risiko Suku Bunga, Risiko Nilai Tukar, dan Leverage terhadap Profitabilitas (Studi pada Perusahaan Subsektor Makanan dan Minuman yang Terdaftar di Bursa Efek Indonesia Tahun 2012-2016). Jurnal Administrasi Bisnis, 50(3), 48-56.

Purnama, H. (2018). Pengaruh Struktur Modal, Kebijakan Deviden, dan Keputusan Investasi Terhadap Profitabilitas (Studi Kasus Perusahaan Manufaktur yang Go Public di Bursa Efek Indonesia Periode 2012-2016). Jurnal Akuntansi Dan Manajemen Akmenika, 15(2), 122-134.

Puspitasari, D. P., \& Suryono, B. (2020). Modal Intelektual, Ukuran Perusahaan Dan Struktur Modal Terhadap Nilai Perusahaan Dengan Profitabilitas Sebagai Variabel Intervening. Jurnal Ilmu Dan Riset Ekonomi, 9(2).

Sari, N. D. A., \& Sidiq, A. (2013). Analisis Financial Leverage, Profitabilitas, dan Earning Per Share (EPS) terhadap Nilai Perusahaan pada Perusahaan Manufaktur yang Terdaftar di Bursa Efek Indonesia (BEI). Jurnal Riset Manajemen Dan Akuntansi, 4(7), 1-20.

Sari, N. P. E., \& Baskara, I. G. K. (2018). Nilai Tukar, Nilai Ekspor, dan Pertumbuhan Ekonomi Terhadap Profitabilitas Eksportir Food and Beverage di BEI. E-Jurnal Manajemen Unud, 7(8), 4181-4210. https://doi.org/https://doi.org/10.24843/EJMUNUD.2018.v7.i08.p6

Sasmitapura, A., \& Djajadikerta, H. (2021). Apakah Financial dan Operational Hedging Efektif Mengurangi Eksposur Nilai Tukar? Jurnal Akuntansi Kontemporer, 13(1), 12-26. https:/ / doi.org/doi.org/10.33508/jako.v13i1.2758

Setiyowati, S. W., Naser, J. A., \& Astuti, R. (2020). Leverage dan Growth Opportunity Mempengaruhi Nilai Perusahaan Melalui Profitabilitas. Jurnal Ekonomi Modernisasi, 16, 31-40. 
https://doi.org/https://doi.org/10.21067/jem.v16i1.4513

Setyaningsih, S. U., Utami, S. S., \& Sriwidodo, U. (2018). Analisis Pengaruh Suku Bunga, Inflasi, dan Nilai Tukar Rupiah Terhadap Profitabilitas Bank Umum Swasta Nasional di Bursa Efek Indonesia. E-Journal Universitas Slamet Riyadi, 18(2), 323-331.

Sianturi, C. N., \& Pangestuti, I. R. D. (2015). Pengaruh Liquidity, Firm Size, Growth Opportunity, Financial Distress, Leverage dan Managerial Ownership terhadap Aktivitas Hedging dengan Instrumen Derivatif. Diponegoro Journal of Management, 4, 1-13.

Sugiono, L. P., \& Christiawan, Y. J. (2013). Analisa Faktor yang Mempengaruhi Likuiditas Pada Industri Ritel yang Terdaftar Pada Bursa Efek Indonesia Tahun 2007-2012. Business Accounting Review, 1(2), 298-305.

Ulfa, M., Puspitaningtyas, Z., \& Bhidari, S. C. (2016). Pengaruh Fluktuasi Nilai Tukar Mata Uang Rupiah-Dolar Terhadap Profitabilitas Perusahaan Manufaktur yang Terdaftar di BEI Periode 2010-2014. Jurnal Ekonomi Dan Bisnis, 10(2), 131-142.

Wardani, W., \& Rudolfus, M. Y. (2016). Dampak Leverage, Kepemilikan Institusional, dan Ukuran Perusahaan, Terhadap Kinerja Perusahaan pada Perusahaan Manufaktur Periode 2011-2015. Jurnal Keuangan Dan Perbankan, 14(1).

Widyagoca, I. G. P. A., \& Lestari, P. V. (2016). Pengaruh Leverage, Growth Opportunities, dan Liquidity Terhadap Pengambilan Keputusan Hedging PT. Indosat Tbk. E-Jurnal Manajemen Unud, 5(2), 1282-1308. https://doi.org/https://ojs.unud.ac.id/index.php/Manajemen/article/vie $\mathrm{w} / 16951$

Yeboah, M., \& Takacs, A. (2019). Does Exchange Rate Matter in Profitability of Listed Companies in South Africa? An Empirical Approach. International Journal of Energy Economics and Policy, 9(6), 171-178. 